\title{
THE EXTENDED MRP MODEL FOR THE EVALUATION AND FINANCING OF SUPERANNUATION SCHEMES IN A SUPPLY CHAIN
}

\author{
David BOGATAJ ${ }^{\mathrm{a}}$, Robert VODOPIVEC ${ }^{\mathrm{b}}$, Marija BOGATAJ ${ }^{\mathrm{c}}$ \\ ${ }^{a} M A T$, St. John's Innovation Centre, Cambridge \\ ${ }^{a}$ Evropska pravna fakulteta, Institut za management nepremičnin, Nova Gorica, SI-5000 \\ ${ }^{b, c}$ MEDIFAS, Mednarodni prehod 6, Vrtojba, SI-5290 Šempeter pri Gorici, Slovenia
}

Received 31 July 2012; accepted 18 November 2012

\begin{abstract}
The retirement age of industrial workers in national pension schemes is being raised. However, many industrial workers are not able to work until they have reached the increased retirement age. This problem is decreasing social security, increasing workers anxiety regarding the future and influencing the quality and timing of production processes. Disruptions and lower quality items produced in one activity cell of a supply chain can have a ripple effect throughout an entire supply chain. To solve this problem, we should put in place supplementary occupational pension schemes, which would compensate firms for the depreciated ability of their elderly workers to work when they have reached the previous retirement age but have not yet reached the new, higher retirement age. This article is introduces a model that is based on extended MRP Theory. The model can be used as a basis for negotiations between employers and employees to keep production at the same level of quality. The trade-off between higher contributions to supplementary occupational pension schemes and lower added values is considered. Contributions enable the early retirement of industrial workers at one or more workplaces in a supply chain, while lower added value is the result of lower quality and the perturbed timing of items that are produced in one or more activity cells of a supply chain: these issues have a ripple effect throughout an entire supply chain. The net present value approach is used.
\end{abstract}

Keywords: labour, superannuation, supply chain, risk, management, decision model.

Reference to this paper should be made as follows: Bogataj, D.; Vodopivec, R.; Bogataj, M. 2013. The extended MRP model for the evaluation and financing of superannuation schemes in a supply chain, Technological and Economic Development of Economy 19(Supplement 1): S119-S133.

JEL Classification: C54, C61, C67, J08, J24, M54, P41.

Corresponding author David Bogataj

E-mail: david.bogataj@mobile-assistance.com 


\section{An introduction to the problem of aging and a superannuation plan for industrial workers in a supply chain}

The demographic development of Europe in the recent past is characterised by two features: (a) birth rates have decreased after the Second World War; and (b) life expectancy has increased continuously over the last sixth decades (EU Commission 2012). In many developed European countries, state unfunded pension liabilities are at least three times as large as the sizes of their economies, and today, the long-term obligations of EU Countries to their existing populations is estimated to be close to 50 trillion $€$ (Mueller et al. 2009 and our own projections). As shown in this study, the largest pension liabilities in terms of percent of GDP can be found in France, Poland, Austria, Germany and Italy (323\%-362\%). Most of the other countries show pension liabilities in the range of 200 to approximately $300 \%$ of GDP (Finland, Portugal, Sweden, Malta, Hungary, the Netherlands, Greece, Slovakia, Spain, Bulgaria and the Czech Republic) and are regarded as having a medium level of pension liabilities. The lowest relative liabilities have been calculated for the United Kingdom (91.2\%) and the Baltic Countries (Lithuania: 179.9\% of GDP and Latvia: 124.8\% of GDP).

During the last few years, study results show, that human capital is crucial for economic growth. In addition, large educational investments are essential (Škare 2011). Relatively little has been written about the importance of pension policy for economic growth. Before the global financial crisis began in 2008, at the beginning of this century, many newcomers and old European Countries had begun to implement pension reforms. In the course of the transition of newcomers' economies, their pension systems endured severe financial pressure. In the reforms, the retirement age was reset from approximately 55 to approximately 60 or 65 years. Due to the prolonged working period, workers often become liabilities, rather than assets for their companies, before they are old enough to retire. Among those employed, the risk of exclusion from working life as a result of a disability pension (Haukenes et al. 2011) varies considerably not only by education, occupation income (Emms 2012) and cause-specific factors (Vahtera et al. 2009), but also by the work environment (Christensen et al. 2008), especially by ergonomic factors (Labriola et al. 2009).

Elderly workers could cause longer lead times and other delays in a supply chain. In addition, they may contribute to lower quality of the produced items in a chain and, consequently, a lower value of the final product. Losses of working capacity are increasing due to serious accidents and occupational diseases that occur during the time remaining until retirement (Šukys et al. 2004).

Historically, occupational pension schemes in logistics and industrial companies where developed to lower the anxiety of workers with respect to how to finance their livelihood after they are no longer able to work as well as required. A superannuation scheme is an organisational pension program that is developed and financed by a company for the benefit of its employees: it enables the employees to retire earlier than is possible according to a public pension scheme and permits the company to employ younger and more reliable workers.

Historically, European welfare retirement systems had the same objectives when they were first developed (at the end of the nineteenth century). Today, with the raising of the retirement age and the prolongation of the working period, the real ability to work in certain 
industrial and logistical workplaces is not taken into account. In addition, the problem of anxiety regarding the ability of a worker to work until the new retirement age is reached is reappearing... Therefore, the new pension schemes with higher retirement ages are not meeting the objectives that they were designed to meet.

In some countries, retirement ages could be reduced, depending on a worker's occupation, but in many countries, these opportunities have been abolished or minimised by the reforms that were made after 1990 . Whereas, the increasing retirement age can contribute the decreasing quality and quantity of production as well as delays and uncertainties regarding whether the products will be produced on time, the influence on the added value in the total supply chain is different in different workplaces. How this phenomenon appears in global supply chains will shortly be presented.

\section{The model for the evaluation of the impact of the increasing retirement age}

The early retirement age, as determined in an occupational pension scheme, could be decreased by increasing the contributions from gross earnings $(1+\alpha) c_{L}$ to the extra occupational pension schemes $\alpha c_{L}$. Thus, if the labour cost would increase from $c_{L}$ to $c_{L}(1+\alpha)$, where $\alpha c_{L}$ is factored into the occupational pension scheme, the retirement age of a worker at the workplace $i$ can be lowered, which could increase the quality and quantity of production in the workplace and reduce the lead time in a supply chain. The benefit to the total supply chain could be evaluated through Grubbström's MRP model using the NPV approach.

Our analysis is based on MRP theory, as found in the papers of Grubbström (1996, 1998, 2007) and later extended to the global supply chain by Bogataj et al. (2011), in which the location is also considered, including regional characteristics, such as the cost of labour. For evaluations of activities in such a supply chain, the Net Present Value (NPV) criterion function is used, as in Bogataj and Grubbström $(2012,2013)$.

We consider an assembly system, in which the components of process $j$ need to be in place $\tau_{j}$ time units before completion and sent from parent node $i$ to $j$ with an additional (transportation) time delay $\tau_{i j}$, in advance. This process can be perturbed by reducing the competencies of aging workers. The input requirements are given as transforms in the generalised transportation-production-input matrix, which is denoted $\breve{H}(s)$. Thus the requirements for the production plan $\tilde{\mathbf{P}}(s)$ written as $\breve{H}(s) \tilde{\mathbf{P}}(s)$ are specified in the frequency domain where:

$$
\breve{\mathbf{H}}(s)=\left[\begin{array}{cccc}
0 & 0 & \cdots & 0 \\
h_{21} e^{s \tau_{21}} & 0 & \cdots & 0 \\
\vdots & \vdots & \ddots & \vdots \\
h_{n 1} e^{s \tau_{n 1}} & h_{n 2} e^{s \tau_{n 2}} & \cdots & 0
\end{array}\right]\left[\begin{array}{ccc}
e^{s \tau_{1}} & \cdots & 0 \\
\vdots & \ddots & \vdots \\
0 & \cdots & e^{s \tau_{n}}
\end{array}\right] .
$$

There are some places of production $i$ where workers work on an item longer than necessary. This occurrence creates additional lead time $\Delta \tau_{i}$, so that the total lead time in such a place is equal to $\tau_{i}+\Delta \tau_{i}$, but on the transportation edges, the lead time is equal to $\tau_{i j}+\Delta \tau_{i j}$. This increase can be described by $\breve{H}^{\prime}(s)$, in which case so that requirements for the 
production plan $\tilde{\mathbf{P}}(s)$, which is a complex-valued function and $s$ is the frequency variable, are described in the frequency domain and would be written as follows:

$$
\left[\begin{array}{cccc}
0 & 0 & \cdots & 0 \\
h_{21} e^{s \tau_{21}} & 0 & \cdots & 0 \\
\vdots & \vdots & \ddots & \vdots \\
h_{n 1} e^{s \tau_{n 1}} & h_{n 2} e^{s \tau_{n 2}} & \cdots & 0
\end{array}\right]\left[\begin{array}{ccc}
e^{s \tau_{1}} & \cdots & 0 \\
\vdots & \ddots & \vdots \\
0 & \cdots & e^{s \tau_{n}}
\end{array}\right] \breve{\mathbf{H}}^{\prime}(s) \tilde{\mathbf{P}}(s)=\breve{\mathbf{H}}(s) \breve{\mathbf{H}}^{\prime}(s) \tilde{\mathbf{P}}(s) .
$$

The volumes of output are given by GP, where the output of item $k$ from running process $j$ at the level $P_{j}(t)$, in terms of volume, is generally $g_{k j} P_{j}(t)$. Here, we shall simplify by setting $\breve{G}(s)=\mathbf{I}$.

The net production of such a system $\tilde{\mathbf{x}}(s)$ will conveniently be written as follows:

$$
\begin{gathered}
\tilde{\mathbf{x}}(s)=\left\{\mathbf{I}-\breve{\mathbf{H}}(s) \breve{\mathbf{H}}^{\prime}(s)\right\} \tilde{\mathbf{P}}(s)= \\
\left\{\mathbf{I}-\left[\begin{array}{cccc}
h_{11} e^{s \tau_{11}} & h_{12} e^{s \tau_{12}} & \cdots & h_{1 n} e^{s \tau_{1 n}} \\
h_{21} e^{s \tau_{21}} & h_{22} e^{s \tau_{22}} & \cdots & h_{2 n} e^{s \tau_{2 n}} \\
\vdots & \vdots & \ddots & \vdots \\
h_{n 1} e^{s \tau_{n 1}} & h_{n 2} e^{s \tau_{n 2}} & \cdots & h_{2 n} e^{s \tau_{n n}}
\end{array}\right]\left[\begin{array}{ccc}
e^{s \tau_{1}} & \cdots & 0 \\
\vdots & \ddots & \vdots \\
0 & \cdots & e^{s \tau_{n}}
\end{array}\right] \breve{\mathbf{H}}^{\prime}(s)\right\} \tilde{\mathbf{P}}(s) .
\end{gathered}
$$

If $\tilde{\mathbf{F}}(s)$ is the vector of deliveries from the system, then, given a plan $\tilde{\mathbf{P}}(s)$, the available inventory $\tilde{\mathbf{R}}(s)$ will develop according to:

$$
\tilde{\mathbf{R}}(s)=\frac{\mathbf{R}(0)+\left\{\mathbf{I}-\breve{\mathbf{H}}(s) \breve{\mathbf{H}}^{\prime}(s)\right\} \tilde{\mathbf{P}}(s)-\tilde{\mathbf{F}}(s)}{s},
$$

where: $\mathbf{R}(0)$ are the initial available inventory levels; and $\mathfrak{E}^{-1}\{\tilde{\mathbf{R}}(s)\} \geq \mathbf{0}$ is the available inventory constraint. For cyclical processes, which repeat themselves in constant time intervals $T_{j}, j=1,2, \ldots, m$, the plan $\tilde{\mathbf{P}}(s)$ is written as suggested by Grubbström (1998):

$$
\tilde{\mathbf{P}}(s)=\left[\begin{array}{ccc}
e^{-s t_{1}} & \cdots & 0 \\
\vdots & \ddots & \vdots \\
0 & \cdots & e^{-s t_{n}}
\end{array}\right]\left[\begin{array}{ccc}
\left(1-e^{-s T_{1}}\right)^{-1} & \cdots & 0 \\
\vdots & \ddots & \vdots \\
0 & \cdots & \left(1-e^{-s T_{n}}\right)^{-1}
\end{array}\right] \hat{\mathbf{P}}=\tilde{\mathbf{t}}(s) \tilde{\mathbf{T}}(s) \hat{\mathbf{P}}
$$

where $\hat{\mathbf{P}}$ is a vector of constants: for instance, $\hat{\mathbf{P}}$ could describe the total amounts (batch sizes) to be produced in (or delivered by) each process during one of the periods $T_{j}, j=1,2, \ldots, n$. Furthermore, in the above equation and where $t_{j}, j=1,2, \ldots, n$, are the points in time when the first of each respective cycle starts. Please refer to the details in (Grubbström 2007), which develop Eq. (5) below:

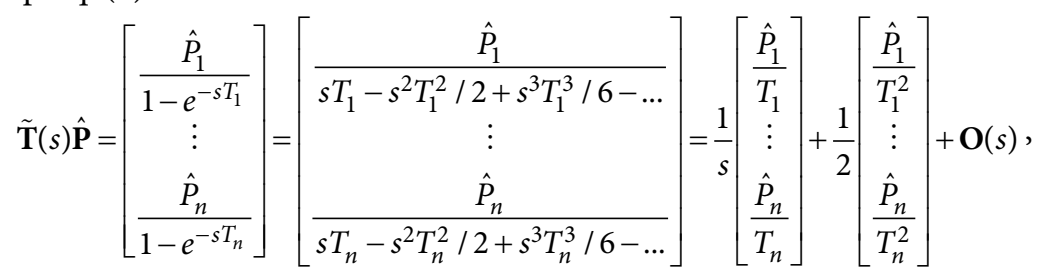

where $\mathbf{O}(s)$ is a vector that vanishes with at least the speed of $s$. 
The balance requirements over time will be as described by Grubbström (1998):

$$
(\mathbf{I}-\mathbf{H})\left[\begin{array}{c}
\hat{P}_{1} / T_{1} \\
\vdots \\
\hat{P}_{n} / T_{n}
\end{array}\right]=\hat{\mathbf{D}},
$$

If the demand for final products in a supply chain is growing by increasing general productivity rate $\omega$, in the long term Eq. (6) is extended thusly:

$$
(\mathbf{I}-\mathbf{H})\left[\begin{array}{c}
\hat{P}_{1} / T_{1} \\
\vdots \\
\hat{P}_{n} / T_{n}
\end{array}\right] e^{\omega \cdot t}=\hat{\mathbf{D}} e^{\omega \cdot t}
$$

\section{The Net Present Value approach}

For a long time, the Net Present Value (NPV) principle has been applied in many productioninventory problems, for example, Hadley (1964), Trippi and Levin (1974), Grubbström (1980), Kim et al. (1986), Grubbström and Thorstenson (1986), Glud Johansen and Thorstenson (1996), Klein Haneveld and Teunter (1998), Teunter and van der Laan (2002), Grubbström and Kingsman (2004), Bogataj et al. (2005), Bogataj, D. and Bogataj, M. (2007), Bogataj, L. and Bogataj, M. (2007). During the last few years, a substantial number of new developments with respect to treating NPV in a supply chain have been reported, for instance, by Chen (2012), Liu and Cruz (2012), Marvin et al. (2013), Kähkönen and Lintukangas (2010), Bogataj et al. (2011), Grubbström (2010), Grubbström et al. (2010), Bogataj and Grubbström (2012, 2013), Grubbström and Bogataj (1998).

We collect the economic values of items into a price vector $\mathbf{p}$, which is a row vector, as follows:

$$
\mathbf{p}=\left[p_{1}, p_{2}, \ldots, p_{n}\right]
$$

Thus, the NPV approach can be presented. In general, each activity cell produces items. Therefore, for a certain production at a certain stage of a supply chain, we can assume:

$$
\mathbf{p}=\mathbf{p}^{1}+\Delta \mathbf{p}=\left[p_{1}^{1}\left(1+\delta_{1}\right), p_{2}^{1}\left(1+\delta_{2}\right), \ldots, p_{n}^{1}\left(1+\delta_{n}\right)\right]
$$

where $\delta_{i}$ is the relative reduction of prices of item $i \quad\left(\delta_{i} \leq 0\right)$, because the worker in production unit $i$ is no longer able to assure the best quality of products, due to his advanced age. We can expect that the majority of places have set these values equal to 0 , but in some workplaces, this reduction of value could appear because of the previously mentioned problem of aging workers and an increased age of retirement. If the owners would invest in ergonomically sound conditions in their workplaces, they could influence the reduction of $\delta_{i}$ by a certain amount.

The major consequences of the industrial revolution have been: (1) growing economies; and (2) aging populations. Both of those effects will be modelled in a supply chain. According to the Net Present Value Theorem (Grubbström 1967), the NPV of the cash flow is obtained 
by substituting the complex frequency $s$ for the continuous interest rate $\rho$ and thereby embedding the time preference of the decision maker in the model, as written in (9).

$$
\mathrm{NPV}=\mathbf{p} \tilde{\mathbf{x}}(\rho)=\sum_{i=1}^{n} p_{i} \tilde{x}_{i}(\rho) .
$$

We shall introduce the general economic growth into model (9). When we consider the economic growth $e^{\omega \cdot t}$ which may be obtained by increasing productivity in the long term, we can write the following equation:

$$
\mathrm{NPV}=\mathbf{p} \tilde{\mathbf{x}}(\rho-\omega)=\sum_{i=1}^{n} p_{i} \tilde{x}_{i}(\rho-\omega) .
$$

In the next step, we introduce the effect of aging due to a higher retirement age and its impact on NPV. After taking the consequences of a lower quality of work into consideration, when aging effects are translated into financial consequences, we may write:

$$
\mathrm{NPV}=\left(\mathbf{p}^{1}+\Delta \mathbf{p}\right) \tilde{\mathbf{x}}(\rho-\omega)=\sum_{i=1}^{n}\left(p_{i}^{1}\left(1+\delta_{i}\right)\right) \tilde{x}_{i}(\rho-\omega) .
$$

However, the old age of industrial workers is not reflected exclusively in the quality of the product but often, in additionally delayed timing as well. These issues cause a perturbation of $\tilde{\mathbf{t}}(s)$, which has to be considered in Eq. (4), therefore a perturbed matrix $\tilde{\mathbf{t}}^{p}$ can be written as a product of two matrices:

$$
\tilde{\mathbf{t}} P(s)=\left[\begin{array}{ccc}
e^{-s\left(t_{1}+\Delta t_{1}\right)} & \cdots & 0 \\
\vdots & \ddots & \vdots \\
0 & \cdots & e^{-s\left(t_{n}+\Delta t_{n}\right)}
\end{array}\right]=\tilde{\mathbf{t}}(s)\left[\begin{array}{ccc}
e^{-s \Delta t_{1}} & \cdots & 0 \\
\vdots & \ddots & \vdots \\
0 & \cdots & e^{-s \Delta t_{n}}
\end{array}\right]=\tilde{\mathbf{t}}(s) \tilde{\mathbf{r}}(s) .
$$

In this case, the ordering costs are:

$$
\mathrm{NPV}_{\text {ordering }}=-\mathbf{K} \tilde{\mathbf{t}}(\rho) \tilde{\mathbf{r}}(\rho) \tilde{\mathbf{T}}(\rho) \sum_{i} e_{i}
$$

where $\sum_{i} e_{i}$ is an $m$-dimensional column vector consisting of unit values.

We also need to take the direct costs of labour into account. The total NPV ( NPV total $)$ should be reduced for the NPV of payments with respect to the labour in individual places of activity with productions $P_{i}$. The results could be written as $c_{i}(p s) L_{i} P_{i}$, where $c_{i}$ is the cost of one unit of work, which also includes the part of gross earnings that is sent to the occupational pension fund, and $L_{i}$ is the amount of work, which needed for the production of one unit of item $i$. We can write: $c_{i}(p s)=(1+\alpha) c_{i}$, where $\alpha$ is the share of the cost of labour that is allocated through an employer contribution to either the pension fund or the occupational pension scheme.

We need to write the net present value of the cost of labour so that it includes the cost of early retirement:

$$
\operatorname{NPV}(p s)=-\sum_{i} c_{i}(p s) L_{i} x_{i}(\rho-\omega)=-\sum_{i} c_{i}\left(1+\alpha_{i}\right) L_{i} x_{i}(\rho-\omega)
$$


In Eq. (13), $\alpha_{i}$ is the rate of payment to the occupational pension fund (for some specific working activities), which could be different for different working activities and is often 0 . In that case, the net present value of all activities in a global supply chain would be as follows:

$$
\begin{aligned}
& \mathrm{NPV}_{\text {tot }}=\mathrm{NPV}+\mathrm{NPV}(\mathrm{ps})+\mathrm{NPV}_{\text {ordering }}= \\
& \sum_{i=1}^{n}\left(p_{i}^{1}\left(1+\delta_{i}\right)\right) \tilde{x}_{i}(\rho-\omega)-\sum_{i=1}^{n} c_{i}\left(1+\alpha_{i}\right) L_{i} \tilde{x}_{i}(\rho-\omega)-\mathbf{K} \tilde{\mathbf{t}}(\rho) \tilde{\mathbf{r}}(\rho) \tilde{\mathbf{T}}(\rho) \sum_{i} e_{i}
\end{aligned}
$$

In the case of a fully funded pension scheme, $\delta_{i}$ would be nearly 0 for any activity $i$, but if we are not able to assume there is an occupational pension fund, so that the workers can not retire before reaching the public retirement age, $\delta_{i}$ would become negative, due to the advanced age of many worker. EU Member States should put in place supplementary occupational pensions schemes, which would compensate tor the reduced capabilities of workers during the period between their original retirement age and the increased retirement age. Therefore these schemes would reduce $\delta_{i}$ to zero and $\tilde{\mathbf{r}}(\rho)$ to I. The contribution to the occupational pension scheme for early retirement is acceptable for the supply chain, if the NPV of contributions to the occupational pension fund $\sum_{i=1}^{n} c_{i} \alpha_{i} L_{i} \tilde{x}_{i}(\rho-\omega)$, as expressed in (14), is less than or equal to the NPV of the costs absorbed in employing elderly workers, which results in a perturbation of the timing and a reduced quality of the manufactured items. This phenomenon is expressed in formula (15) below:

$$
\sum_{i=1}^{n} c_{i} \alpha_{i} L_{i} \tilde{x}_{i}(\rho-\omega) \leq \sum_{i=1}^{n} p_{i}^{1} \delta_{i} \tilde{x}_{i}(\rho-\omega)+\mathbf{K} \tilde{\mathbf{t}}(\rho)\{\mathbf{I}-\tilde{\mathbf{r}}(\rho)\} \tilde{\mathbf{T}}(\rho) \sum_{i} e_{i}
$$

The evaluation of the production items' qualities should be conducted on the level of a supply chain and not only for the individual worker who manipulates item $i$, because only on this level may the impact of delays on the criterion function be evaluated correctly. Participation in the occupational pension fund is sustainable, when the net present value of all contributions to this scheme does not exceed the net present value of the supply chain growth in the case of no perturbations, due to the old ages of workers:

$$
\begin{aligned}
& \sum_{i=1}^{n} c_{i} \alpha_{i} L_{i} \tilde{x}_{i}(\rho-\omega) \leq \sum_{i=1}^{n} p_{i} \tilde{x}_{i}(\rho-\omega)-\sum_{i=1}^{n} p_{i} \tilde{x}_{i}(\rho)+ \\
& \mathbf{K}\{\tilde{\mathbf{t}}(\rho-\omega) \tilde{\mathbf{T}}(\rho-\omega)-\tilde{\mathbf{t}}(\rho) \tilde{\mathbf{T}}(\rho)\} \sum_{i} e_{i} .
\end{aligned}
$$

Participation in the occupational pension fund should be a result of negotiation between unions and employers, who would decide how to share the results of economic growth $e^{\omega t}$ that are described by the right side of Eq. (16), for active workers, improvements of their workplaces (investments), retired persons and employers. The problem appears when the growth is negligible, which is currently the case in many European countries. 


\section{A numerical example}

In this section, we provide a numerical example of the case of an assembly network. It is similar to the one described in Bogataj and Grubbström (2012), whose product structure is depicted in Figure 1.

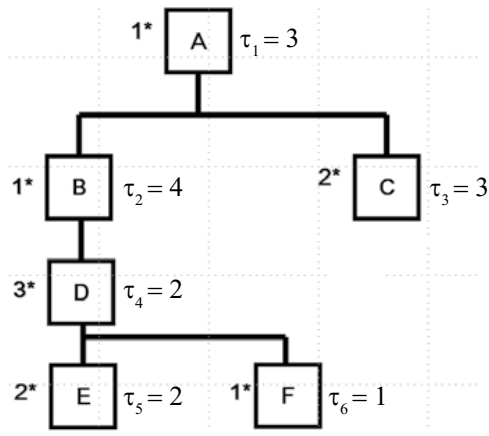

Fig. 1. An example of a traditional supply chain structure of an assembly type, it is from Bogataj and Grubbström (2012)

According to Figure 1, there are six activities and products (items). Activity D represents the assembly of 2 units of item $E$ and 1 unit of item $F$, activity $B$ requires 3 units of $D$ for the production of one unit of $\mathrm{B}$, and at the top level activity $\mathrm{A}$ demands 1 unit of $\mathrm{B}$ and 2 units of $\mathrm{C}$ for the production of one unit of the end product A. Activities $\mathrm{C}$ and $\mathrm{D}$ are executed by elder workers, where $\tau_{3}$ and $\tau_{4}$ were initially 3 and 2 , respectively However, beginning at the initial time these values increase $30 \%$ to $3(1+0.3)$ and $2(1+0.3)$, respectively. Transportation times in this example are shown in the left part of Table 1, and the production lead times are shown in the bottom row. As an example, item $D$ entering $B$ is required to be available 4 time units in advance of the completion of $B$, but transportation to $B$ adds another $2(1+0.3 \mathrm{t})$ time units when $\mathrm{D}$ is to be ordered. This results in the values $\tau_{42}=\tau_{\mathrm{DB}}=6$, and the operator multiplying the element $h_{42}=h_{\mathrm{DB}}$ will be $e^{6 s}$. The resulting individual lead times for each element in $\breve{H}(s)$ are shown on the right side of Table 1.

Table 1. The transportation time distance between the nodes and the production lead times of the example, where perturbations in delay at $\mathrm{C}$ and $\mathrm{D}$ appear as $30 \%$ of the initial value

\begin{tabular}{c|c|c|c|c|c|c|c|c|c|c|c|c}
\hline \multicolumn{10}{c}{ Transportation lead time } \\
\hline From/to & $A$ & $B$ & $C$ & $D$ & $E$ & $F$ & $A$ & $B$ & $C$ & $D$ & $E$ & $F$ \\
\hline$A$ & & & & & & & 3 & 4 & $3(1+0.3)$ & $2(1+0.3)$ & 2 & 1 \\
\hline$B$ & 4 & & & & & & 7 & 4 & $3(1+0.3)$ & $2(1+0.3)$ & 2 & 1 \\
\hline$C$ & 3 & & & & & & 6 & 4 & $3(1+0.3)$ & $2(1+0.3)$ & 2 & 1 \\
\hline$D$ & & 2 & & & & & 3 & 6 & $3(1+0.3)$ & $2(1+0.3)$ & 2 & 1 \\
\hline$E$ & & & & 3 & & & 3 & 4 & $3(1+0.3)$ & $5+0.6$ & 2 & 1 \\
\hline$F$ & & & & 1 & & & 3 & 4 & $3(1+0.3)$ & $3+0.6$ & 2 & 1 \\
\hline $\begin{array}{c}\text { Production } \\
\text { lead time }\end{array}$ & 3 & 4 & $3(1+0.3)$ & $2(1+0.3)$ & 2 & 1 & \multicolumn{7}{c}{ Time entries for operators } \\
\hline \multicolumn{2}{c}{} & & & & & & & & & \\
\hline
\end{tabular}


Thus, the input matrix and the generalised input matrix are as follows:

$$
\mathbf{H}=\left[\begin{array}{llllll}
0 & 0 & 0 & 0 & 0 & 0 \\
1 & 0 & 0 & 0 & 0 & 0 \\
2 & 0 & 0 & 0 & 0 & 0 \\
0 & 3 & 0 & 0 & 0 & 0 \\
0 & 0 & 0 & 2 & 0 & 0 \\
0 & 0 & 0 & 1 & 0 & 0
\end{array}\right], \breve{H}(s)=\left[\begin{array}{cccccc}
0 & 0 & 0 & 0 & 0 & 0 \\
1 e^{7 s} & 0 & 0 & 0 & 0 & 0 \\
2 e^{6 s} & 0 & 0 & 0 & 0 & 0 \\
0 & 3 e^{6 s} & 0 & 0 & 0 & 0 \\
0 & 0 & 0 & 2 e^{(5+0,6) s} & 0 & 0 \\
0 & 0 & 0 & 1 e^{(3+0,6) s} & 0 & 0
\end{array}\right] .
$$

We shall now evaluate the system according to the Net Present Value principle (NPV), provided that the values of economic parameters concerning the unit production prices/costs $\mathbf{p}$ and the setup costs $\mathbf{K}$ and an interest rate $\rho$ are introduced (and interpreted as elements of the relevant cash flow). Let us assume the following values $\mathbf{p}=\left[560,38,25+\delta_{C}, 34+\delta_{D}, 14,15\right]$, where $\delta$ describes the negative value that is a result of the lower quality of manufactured items, because the workers at positions $\mathrm{C}$ and $\mathrm{D}$ cannot produce the highest quality of items C and D: in addition $\rho=\rho_{0}-\omega=0.07-\omega$. Here, $\omega$ represents the growth of the flows of a supply chain (the growth of economy in general). From the Net Present Value Theorem and (14) we then obtain the NPV of the cash flow involved, which is as follows:

$$
\begin{aligned}
& \mathrm{NPV}=\sum_{i=1}^{n}\left(p_{i}^{1}\left(1+\delta_{i}\right)\right) \tilde{x}_{i}(\rho-\omega)-\sum_{i=1}^{n} c_{i}\left(1+\alpha_{i}\right) L_{i} \tilde{x}_{i}(\rho-\omega)- \\
& \mathbf{K} \tilde{\mathbf{t}}(\rho) \tilde{\mathbf{r}}(\rho) \tilde{\mathbf{T}}(\rho) \sum_{i} e_{i} \\
& \quad \mathbf{x}(\rho-\omega)=\mathbf{p}(\mathbf{I}-\breve{\mathbf{H}}(\rho-\omega)) \tilde{\mathbf{P}}(\rho-\omega),
\end{aligned}
$$

where we have substituted the Laplace frequency s (in the general case) for the continuous interest rate $\rho$. However, because the productivity is supposed to grow, we assumed that the production is growing by $e^{\omega t}$ and therefore $\tilde{x}_{i}=\tilde{x}_{i}(\rho-\omega)$. For the sake of simplicity, we shall assume that aging does not influence the setups. In this case, we have obtained $\tilde{\mathbf{r}}(\rho)=\mathbf{I}$ in Eq. (15).

Let us assume as in Bogataj and Grubbström (2012), that production is to take place at regular intervals of lengths $T_{i}=15,13,10,13,10$ and 13, and let us assume that the first batch is to start at times $t_{i}=22,18,14,10,6$ and 2, respectively. The transform of production activities $\tilde{\mathbf{P}}(s)$ is:

$$
\tilde{\mathbf{P}}(s)=\left[\begin{array}{c}
\vdots \\
\frac{\hat{P}_{i} e^{-s t_{i}}}{1-e^{-s T_{i}}} \\
\vdots
\end{array}\right],
$$

where the $\hat{P}_{i}$ are the constant batch sizes, which are assumed to have the values of 100, 100, $200,300,600$ and 300, respectively. The setup vector represents a sequence of unit impulses taking place at the same time as the production batches. 
Given the numerical values assumed in this example, when $s=\rho-\omega=0.065$, we obtain the following difference between NPV in the case when the elderly are forced to work longer than it is possible for them to work without either a reduction of quality or timing perturbations at $C$ and $D$ and NPV in the same chain, if workers are working without these perturbations:

$$
\begin{aligned}
& \Delta \mathrm{NPV}_{\text {aging }}= \\
& {\left[560,38,25+\delta_{C}, 34+\delta_{D}, 14,15\right]\left[\begin{array}{cccccc}
1 & 0 & 0 & 0 & 0 & 0 \\
-e^{7(\rho-\omega)} & 1 & 0 & 0 & 0 & 0 \\
-2 e^{6(\rho-\omega)} & 0 & 1 & 0 & 0 & 0 \\
0 & -3 e^{6(\rho-\omega)} & 0 & 1 & 0 & 0 \\
0 & 0 & 0 & -2 e^{5,6(\rho-\omega)} & 1 & 0 \\
0 & 0 & 0 & -e^{3,6(\rho-\omega)} & 0 & 1
\end{array}\right]\left[\begin{array}{r}
38.42 \\
54.41 \\
168.44 \\
274.55 \\
849.94 \\
461.80
\end{array}\right]-} \\
& {[560,38,25,34,14,15]\left[\begin{array}{cccccc}
1 & 0 & 0 & 0 & 0 & 0 \\
-e^{7(\rho-\omega)} & 1 & 0 & 0 & 0 & 0 \\
-2 e^{6(\rho-\omega)} & 0 & 1 & 0 & 0 & 0 \\
0 & -3 e^{6(\rho-\omega)} & 0 & 1 & 0 & 0 \\
0 & 0 & 0 & -2 e^{5(\rho-\omega)} & 1 & 0 \\
0 & 0 & 0 & -e^{3(\rho-\omega)} & 0 & 1
\end{array}\right]\left[\begin{array}{r}
38.42 \\
54.41 \\
168.44 \\
274.55 \\
849.94 \\
461.80
\end{array}\right]=}
\end{aligned}
$$

$-76.84 \delta_{C} e^{6(\rho-\omega)}-163.23 \delta_{D} e^{6(\rho-\omega)}+168.44 \delta_{C}+274.55\left(\delta_{D}-28\left(e^{5.6(\rho-\omega)}-e^{5(\rho-\omega)}\right)-\right.$ $\left.15\left(e^{3.6(\rho-\omega)}-e^{3(\rho-\omega)}\right)\right)=\left(168.44-76.84 e^{6(\rho-\omega)}\right) \delta_{C}+\left(274.55-163.23 e^{6(\rho-\omega)}\right) \delta_{D}-$ $7687.40\left(e^{5.6(\rho-\omega)}-e^{5(\rho-\omega)}\right)-4118.25\left(e^{3.6(\rho-\omega)}-e^{3(\rho-\omega)}\right)$.

The supply chain is losing NPV due to decreasing qualities of production or to different delay perturbations in the workplaces, where the elderly are working as presented in Table 2.

Table 2. The differences in NPV between the activities without reduced quality and perturbations in the production lead times and the examples in which perturbed delays at $\mathrm{C}$ and $\mathrm{D}$ appear as $30 \%$ of the initial value and the quality of production influence the prices of items by $\delta$

\begin{tabular}{c|c|c|c|c}
\hline \multicolumn{2}{c}{${ }^{2}-\delta_{C}$} & $-\delta_{D}$ & $\begin{array}{c}e^{\rho-\omega} \\
(\rho=0.07)\end{array}$ & $\Delta \mathrm{NPV}_{\text {aging }}$ \\
\hline \multirow{4}{*}{0,005} & 1 & 1.5 & & -104.08 \\
\cline { 2 - 3 } & 2 & 3.0 & & -209.22 \\
\cline { 2 - 3 } & 3 & 4.5 & & -314.36 \\
\cline { 2 - 3 } & 4 & 6.0 & & -419.50 \\
\cline { 2 - 3 } & 5 & 7.5 & \multirow{4}{*}{1,0618} & -524.65 \\
\cline { 2 - 3 } & 10 & 15.0 & & -1050.36 \\
\cline { 2 - 3 } & 13 & 18.8 & & -1313.21 \\
\hline
\end{tabular}


It is better to replace the elderly with younger workers if the net present value of all contributions to the fund are lower than the increases of NPV that are achieved by younger workers, i.e. if:

$$
\sum_{i} c_{i} \alpha_{i} L_{i} x_{i}(\rho-\omega) \leq \Delta \mathrm{NPV}_{\text {aging }}
$$

Thus, in the case when we have only one worker at each activity cell, who is paid 9, 10, 12, 6, 4 and 2 monetary units, respectively, for activities from A to F, and for each item manipulated in any activity cell, if the employers are paying at each salary also $\alpha$ uniformly to the pension scheme, then the following conditions have to be fulfilled:

$\alpha\left[\begin{array}{llllll}9 & 10 & 12 & 6 & 4 & 2\end{array}\right]\left[\begin{array}{cccccc}1 & 0 & 0 & 0 & 0 & 0 \\ -e^{7(\rho-\omega)} & 1 & 0 & 0 & 0 & 0 \\ -2 e^{6(\rho-\omega)} & 0 & 1 & 0 & 0 & 0 \\ 0 & -3 e^{6(\rho-\omega)} & 0 & 1 & 0 & 0 \\ 0 & 0 & 0 & -2 e^{5(\rho-\omega)} & 1 & 0 \\ 0 & 0 & 0 & -e^{3(\rho-\omega)} & 0 & 1\end{array}\right]\left[\begin{array}{r}38.42 \\ 54.41 \\ 168.44 \\ 274.55 \\ 849.94 \\ 461.80\end{array}\right] \leq-\Delta \mathrm{NPV}_{\text {aging }}$

From here, it follows that in the case where $\rho-\omega=0.065$ :

$$
\alpha \leq-\Delta \mathrm{NPV}_{\text {aging }} / 1760.46 \text {. }
$$

Table 3 presents the upper limit of $\alpha$ which could be uniformly attached to each working place in a chain to enable the occupational pension fund and to replace elderly workers with younger workers at $\mathrm{C}$ and $\mathrm{D}$, at different reductions of quality $\delta$ and $30 \%$ of the prolonged lead time.

Table 3. The upper limit of $\alpha$ at different combinations of $\delta_{C}$ and $\delta_{D}$, assuming there is a 30\% prolonged

\begin{tabular}{|c|c|c|c|c|c|c|}
\hline$-\delta_{C}$ & $-\delta_{D}$ & $\begin{array}{c}e^{\rho-\omega} \\
(\rho=0.07)\end{array}$ & $\begin{array}{l}\Delta \mathrm{NPV}_{\text {aging }} \\
(\omega=0.005)\end{array}$ & $\begin{array}{c}\Delta \mathrm{NPV}_{\text {aging }} \\
(\omega=0.05)\end{array}$ & $\begin{array}{c}\text { Upper limit of } \\
\alpha(\omega=0.005)\end{array}$ & $\begin{array}{c}\text { Upper limit of } \\
\alpha(\omega=0.05)\end{array}$ \\
\hline 1 & 1.5 & \multirow{5}{*}{1.0618} & -104.08 & -216.55 & 0.06 & 0.026 \\
\hline 2 & 3.0 & & -209.22 & -434.11 & 0.12 & 0.051 \\
\hline 3 & 4.5 & & -314.36 & -651.68 & 0.18 & 0.077 \\
\hline 4 & 6.0 & & -419.50 & -869.24 & 0.24 & 0.103 \\
\hline 5 & 7.5 & & -524.65 & -1086.81 & 0.30 & 0.129 \\
\hline
\end{tabular}
lead time for $0.5 \%$ of the production growth at $\mathrm{C}$ and $5 \%$ of the production growth at $\mathrm{D}$

For example, let us consider the case in which $\omega=0.005$. From the perspective of a total supply chain it is better to pay up to $12 \%$ of salary additionally (for any worker in the supply chain, at each working place), to the occupational pension fund. This payment will give a firm the ability to replace old workers at $C$ and $D$ with younger workers, when the timing and quality of production of the elderly workers is no longer sufficient. In this case (row 2) it is better to pay an additionally $12 \%$ of a workers salary to the occupational pension fund than to have $2 / 25$ fewer valued products at $C, 3 / 34$ fewer valued products at $D$ and $30 \%$ prolonged lead time in these workplaces. If productivity is rising by $5 \%$ per annum, the upper limit of $\alpha$ decreases to $5.1 \%$ of all salaries. 


\section{Conclusions}

In this paper, we have illustrated how to use extensions of MRP theory in the total supply chain (EMRP) for the purposes of planning the retirement age of industrial and logistics workers. Workers in the EU are living increasingly longer. This phenomenon requires greater participation in pension funds and because of that, the retirement ages in the national pension schemes of developed countries are increasing. However, many industrial workers are not able to work until they reach the increased retirement age. This problem is decreasing the social security of industrial workers, increasing their anxiety regarding the future and influencing the decreasing quality of production processes with respect to the perturbations of timing and the quality of the products.

To solve this problem, the EU Member States should put in place supplementary occupational pension schemes, which would allow the early retirement of those who, at a certain age, become at a certain age more of a liability than an asset in the eyes of supply chain managers. For an evaluation of a supply chain, the NPV approach could be used as bases for negotiations between employers and employees. The net present value approach was used in the case of rising productivity, which influences the growth of a supply chain.

The contribution rate to the occupational pension fund should be a result of negotiation between unions and employers, who would decide how to share the results of economic growth among active workers for their salaries and pension fund contributions, how to share the profit margin, which also covers further investments in ergonomic design of the workplaces, and how to attract consumers in the form of lower prices of products. If an employer gains a higher share, he can invest in the workplace so, that the work will be easier for the elderly. The problem appears when growth is negligible.

\section{References}

Bogataj, D.; Bogataj, M. 2007. Measuring the supply chain risk and vulnerability in frequency space, International Journal of Production Economics 108(1-2): 291-301. http://dx.doi.org/10.1016/j.ijpe.2006.12.017

Bogataj, L.; Bogataj, M. 2007. The study of optimal additional investments in capacities for reduction of delays in value chain, International Journal of Production Economics 108(1-2): 281-290. http://dx.doi.org/10.1016/j.ijpe.2006.12.016

Bogataj, M.; Grubbström, R.W. 2012. On the representation of timing for different structures within MRP theory, International Journal of Production Economics 140(2): 749-755. http://dx.doi.org/10.1016/j.ijpe.2011.04.016

Bogataj, M.; Grubbström, R.W. 2013. Transportation delays in reverse logistics, International Journal of Production Economics. 143(2): 395-402. http://dx.doi.org/10.1016/j.ijpe.2011.12.007

Bogataj, M.; Bogataj, L.; Vodopivec, R. 2005. Stability of perishable goods in cold logistic chains, International Journal of Production Economics 93-94: 345-356. http://dx.doi.org/10.1016/j.ijpe.2004.06.032

Bogataj, M.; Grubbström, R.W.; Bogataj, L. 2011. Efficient location of industrial activity cells in a global supply chain, International Journal of Production Economics 133(1): 243-250. http://dx.doi.org/10.1016/j.ijpe.2010.09.035

Chen, A. H.-L.; Liang,Y.-C.; Liu, C.-C. 2012. An artificial bee colony algorithm for the cardinality-constrained portfolio optimization problems, IEEE Congress on Evolutionary Computation 2012: 1-8. 
Christensen, K. B.; Feveile, H.; Labriola, M.; Lund, T. 2008. The impact of psychosocial work environment factors on the risk of disability pension in Denmark, European Journal of Public Health 18: 235-237. http://dx.doi.org/10.1093/eurpub/ckm130

Emms, P. 2012. Lifetime investment and consumption using a defined-contribution pension scheme, Journal of Economic Dynamics and Control 36(9): 1303-1321.

http://dx.doi.org/10.1016/j.jedc.2012.01.012

European Commission official site [online]. 2012. The 2012 ageing report: underlying assumptions and projection [online], [cited 5 June 2012]. Available from Internet:

http://www.ec.europa.eu/economy_finance/publications/.../ee-2011-4_en.pdf

Glud Johansen, S.; Thorstenson, A. 1996. Optimal (r, Q) inventory policies with Poisson demands and lost sales: discounted and undiscounted cases, International Journal of Production Economics 46-47: 359-371. http://dx.doi.org/10.1016/S0925-5273(96)00083-7

Grubbström, R. W. 1967. On the application of the Laplace transform to certain economic problems, Management Science 13(7): 558-567. http://dx.doi.org/10.1287/mnsc.13.7.558

Grubbström, R. W. 1980. A principle for determining the correct capital costs of work-in-progress and inventory, International Journal of Production Research 18: 259-271. http://dx.doi.org/10.1080/00207548008919665

Grubbström, R. W. 1998. A net present value approach to safety stocks in planned production, International Journal of Production Economics 56-57: 213-229. http://dx.doi.org/10.1016/S0925-5273(97)00094-7

Grubbström, R. W. 1996. Material requirements planning and manufacturing resources planning, in Warner, M. (Ed.). International Encyclopedia of Business and Management. London: Routledge.

Grubbström, R. W.; Bogataj, L. (Eds.) 1998. Input-output analysis and Laplace transforms in material requirements planning. Storlien 1997. FPP Portorož.

Grubbström, R. W. 2007. Transform methodology applied to some inventory problems, Zeitschrift für Betriebswirtschaft 77(3): 297-324. http://dx.doi.org/10.1007/s11573-007-0022-7

Grubbström, R. W.; Kingsman, B. G. 2004. Ordering and inventory policies for step changes in the unit item cost: a discounted cash flow approach, Management Science 50: 253-267. http://dx.doi.org/10.1287/mnsc.1030.0150

Grubbström, R. W.; Thorstenson, A. 1986. Evaluation of capital costs in a multi-level inventory system by means of the annuity stream principle, European Journal of Operational Research 24: 136-145. http://dx.doi.org/10.1016/0377-2217(86)90019-6

Grubbström, R. W. 2010. The Newsboy problem when customer demand is a compound renewal process, European Journal of Operational Research 203: 134-142. http://dx.doi.org/10.1016/j.ejor.2009.06.032

Grubbström, R. W.; Bogataj, M.; Bogataj, L. 2010. Optimal lotsizing within MRP theory, Annual Reviews in Control 34(1): 89-100. http://dx.doi.org/10.1016/j.arcontrol.2010.02.004

Hadley, G. 1964. A comparison of order quantities using the average annual costs and the discounted costs, Management Science 10: 472-476. http://dx.doi.org/10.1287/mnsc.10.3.472

Haukenes, I.; Mykletun, A.; Knudsen, A. K.; Hansen, H.-T.; Mæland, J. G. 2011. Disability pension by occupational class - the impact of work-related factors: The Hordaland Health Study Cohort, BMC Public Health 11(1): 406. http://dx.doi.org/10.1186/1471-2458-11-406

Kähkönen, A-K.; Lintukangas, K. 2010. Dyadic relationships and power within a supply network context, Operations and Supply Chain Management: An International Journal 3(2): 59-69.

Kim, Y. H.; Philippatos, G. C.; Chung, K. H. 1986. Evaluating investment in inventory policy: a net present value framework, Engineering Economist 31: 119-136. http://dx.doi.org/10.1080/00137918608902931

Klein Haneveld, W. K.; Teunter, R. H. 1998. Effects of discounting and demand rate variability on the EOQ, International Journal of Production Economics 54: 173-192.

http://dx.doi.org/10.1016/S0925-5273(97)00142-4 
Labriola, M.; Feveile, H.; Christensen, K. B.; Stroyer, J.; Lund, T. 2009. The impact of ergonomic work environment exposures on the risk of disability pension: prospective results from DWECS/DREAM, Ergonomics 52: 1419-1422. http://dx.doi.org/10.1080/00140130903067771

Liu, Z.; Cruz, J. M. 2012. Supply chain networks with corporate financial risks and trade credits under economic uncertainty, International Journal of Production Economics 137(1): 55-67. http://dx.doi.org/10.1016/j.ijpe.2012.01.012

Marvin, W. A.; Schmidt, L. D.; Benjaafar, S.; Tiffany, D. G.; Daoutidis, P. 2013. economic optimization of a lignocellulosic biomass-to-ethanol supply chain, Chemical Engineering Science 67(1): 68-79. http://dx.doi.org/10.1016/j.ces.2011.05.055

Mueller, C.; Raffelhueschen, B.; Weddige, O. 2009. Pension obligations of government employer pension schemes and social security pension schemes established in EU countries, Research Center for Generational Contracts Freiburg University, Freiburg, Bergen.

Škare, M. 2011. How important is human capital for growth in reforming economies?, Technological and Economic Development of Economy 17(4): 667-687. http://dx.doi.org/10.3846/20294913.2011.635221

Šukys, R.; Čyras, P.; Jakutis A.; Stankiuviene, A. 2004. Economical and social consequences of accidents at work and occupational diseases, Technological and Economic Development of Economy 10(1): 26-31.

Teunter, R. H.; van der Laan, E. 2002. On the non-optimality of the average cost approach for inventory models with remanufacturing, International Journal of Production Economics 79: 67-73. http://dx.doi.org/10.1016/S0925-5273(00)00085-2

Trippi, R. R.; Levin, D. E. 1974. A present value formulation of the classical EOQ problem, Decision Science 5: 30-35. http://dx.doi.org/10.1111/j.1540-5915.1974.tb00592.x

Vahtera, J.; Laine, S.; Virtanen, M.; Oksanen, T.; Koskinen, A.; Pentti, J.; Kivimaki, M. 2009. Employee control over working times and risk of cause-specific disability pension: the Finnish Public Sector Study, Occupational and Environmental Medicine 67: 479-485. http://dx.doi.org/10.1136/oem.2008.045096

David BOGATAJ received BSc in Insurance Engineering, University of Ljubljana, FPP in 1997 and defended Diploma Thesis in Transportation Technology in 2000. He received Master of Actuarial Science (Joint program at University of Ljubljana in cooperation with Faculty of Actuaries Edinburgh and Institute of Actuaries, Oxford) in 2001. He is Qualified Actuary and full member of Slovenian Actuarial Society since 2011. He received his PhD at European Faculty of Law in 2012, where he is employed as Assistant Professor. He is partly employed also as a Research Fellow at MEDIFAS since 2012. He is Elected Representative of Slovenian Association of Actuaries in EUROPEAN ACTUARIAL CONSULTATIVE GROUP in Brussels (GROUPE CONSULTATIF ACTUARIEL EUROPEEN). He is author of many Slovenian pension schemes at insurance companies and public institutions. He wrote 7 scientific articles, 10 papers in Proceedings and 6 books or part of books.

Robert VODOPIVEC received BSc Degree in Economics (1984) and MSc Degree (Business policy and organisation, 1990). He continued as research fellow at University of Massachusetts USA and after returning home he defended his $\mathrm{PhD}$ Thesis at University of Maribor in 1996. He has become assistant professor at University of Ljubljana, FPP. He was Visiting Professor at many institutions of higher education. Since 2010 he is partly employed at Faculty of Organization Studies, where he was Vice Dean for research since 2010 till this autumn. He is also director of MEDIFAS. He wrote 11 scientific articles, 11 invited papers and 22 other papers in Proceedings, 27 books or part of books and many national and international research reports. 
Marija BOGATAJ received Math. BSc Degree (1974), MSc Degree (Operations Research, 1978) and Doctor of Engineering Science-Spatial (Urban) modelling - Degree at University of Ljubljana in 1983. She started university career as a lecturer at University of Maribor. In 1994 she was elected Full Professor of Operations Research and Statistics at University of Ljubljana, teaching also Actuarial mathematics, Location theory and Supply chain topics. She was Dean of Faculty of Maritime Studies and Transportation 1993-1999. She is now Head of department for Quantitative Methods at Faculty of Organizational Studies and Head of CERRISK at MEDIFAS. She is supervisor of some master and doctoral students at University of Ljubljana and Independent Faculty of Organizational Studies. During 38 years teaching at University she was/is member of many Scientific Committees of International, Slovenian, Czech and Croatian Journals and Proceedings. In the last 20 years she was visiting professor at many EU Universities. She is author, co-author, or editor/coeditor, of 25 books, author or co-author of 168 articles, essays and working papers, of which 61 have been published in highly ranked scientific journals. She was leading researcher or participated substantially at 49 national and international research projects. 